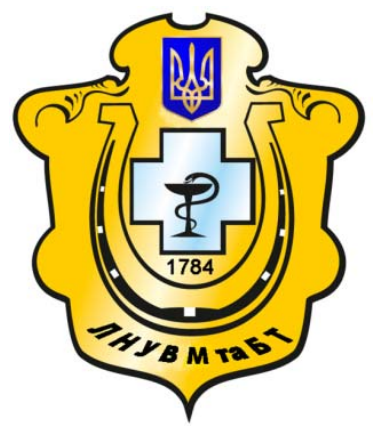

Науковий вісник Львівського національного університету ветеринарної медицини та біотехнологій імені С.3. Гжицького

Scientific Messenger of Lviv National University of Veterinary Medicine and Biotechnologies named after S.Z. Gzhytskyj

doi:10.15421/nvlvet7112

ISSN 2413-5550 print

ISSN 2518-1327 online

$\underline{\text { http://nvlvet.com.ua/ }}$

УДК 619:616.33:636.087.8:636.4.053

\title{
Вплив пробіотика та фітобіотика на кишковий мікробіоценоз відлучених поросят за неспецифічного гастроентериту
}

\author{
Б.О. Лукащук, Л.Г. Слівінська \\ lukaw4yk@gmail.com
}

\begin{abstract}
Львівський наџіональний університет ветеринарної медицини та біотехнологій імені С.3. Гжицького, вул. Пекарська, 50, м. Львів, 79010, Україна
\end{abstract}

У статті представлені результати впливу пробіотика ТОЙОЦЕРІН $10^{9}$ та фітобіотика ЕКСТРАКТтм 6930 в складі основного раціону відлучених поросят хворих неспецифічним гастроентеритом у поєднанні з антибіотиком (10\% розчин енрофлоксацину гідрохлориду) на кишковий мікробіоченоз в умовах сучасного свинокомплексу.

При застосуванні пробіотика та фітобіотика у поєднанні з антибіотиком основні клінічні симптоми захворювання у поросят третьої та четвертої дослідних груп зникали через 3 доби після лікування, тоді як у поросят 2 дослідної групи на 5 добу.

В результаті проведених мікробіологічних досліджень фекалій відлучених поросят хворих неспецифічним гастроентеритом встановлено зміни складу мікрофлори кишечнику.

Застосування пробіотика ТОЙОЦЕРІН $10^{9}$ та фітобіотика ЕКСТРАКТТм 6930 у поєднанні з антибіотиком (10\% розчин енрофлоксаиину гідрохлориду) відлученим поросятам протягом 5 діб сприяло зменшенню кількості умовно-патогенної мікрофлори до рівня показників клінічно здорових поросят.

Встановлено позитивний вплив пробіотика та фітобіотика у поєднанні з антибіотиком на молочнокислу мікрофлору шлунково-кишкового тракту, на щзо вказує нормалізація кількості представників родів Bifidobacterium ma Lactobacillus.

Ключові слова: відлучені поросята, антибіотик, пробіотик, фітобіотик, кишковий мікробіоченоз, неспецифічний гастpoeнтерum, Enterococcus, Staphylococcus, Escherichia coli, Bifidobacterium, Lactobacillus, Candida.

\section{Влияние пробиотика и фитобиотика на кишечный микробиоценоз поросят-отьемышей при неспецифическом гастроэнтерите}

\author{
Лукащук Б.А., Сливинская Л.Г. \\ lukaw4yk@gmail.com
}

\begin{abstract}
Львовский национальный университет ветеринарной медицины и биотехнологий имени С.3. Гжицкого, ул. Пекарская, 50, г. Львов, 79010, Украина
\end{abstract}

В статье представлены результаты влияния пробиотика ТОЙОЦЕРИН $10^{9}$ и фитобиотика ЭКСТРАКТтм 6930 в составе основного рациона поросят-отъемышей больных неспецифическим гастроэнтеритом в сочетании с антибиотиком (10\% раствор энрофлоксачина гидрохлорида) на кишечный микробиоченоз в условиях современного свинокомплекса.

При применении пробиотика и фитобиотика в сочетании с антибиотиком основные клинические симптомы заболевания у поросят третьей и четвертой опытных групп исчезали через 3 суток после лечения, тогда как у поросят 2 опытной группь - на 5 сутки.

В результате проведенных микробиологических исследований фекалий поросят-отъемышей больных неспецифическим гастроэнтеритом установлено изменение состава микрофлоры кишечника.

Применение пробиотика ТОЙОЦЕРИН $10^{9}$ и фитобиотика ЭКСТРАКТТм 6930 в сочетании с антибиотиком (10\% раствор энрофлоксаиина гидрохлорида) поросятам-отъемышам в течение 5 суток способствовало уменьшению количества условно-патогенной микрофлоры до уровня показателей клинически здоровых поросят.

\section{Citation:}

Lukashchuk, B.O., Slivinska, L.G. (2016). Influence of probiotic and phytobiotic on intestinal microbiota of weaned piglets for nonspecific gastroenteritis. Scientific Messenger LNUVMBT named after S.Z. Gzhytskyj, 18, 3(71), 54-58. 
Также установлено положительное влияние пробиотика и фитобиотика в сочетании с антибиотиком на молочнокислую микрофлору желудочно-кишечного тракта, на что указывает нормализация количества представителей родов Bifidobacterium u Lactobacillus.

Ключевые слова: поросята-отъемыии, антибиотик, пробиотик, фитобиотик, кишечный микробиоценоз, неспецифический гастроэнтерит, Enterococcus, Staphylococcus, Escherichia coli, Bifidobacterium, Lactobacillus, Candida.

\title{
Influence of probiotic and phytobiotic on intestinal microbiota of weaned piglets for nonspecific gastroenteritis
}

\author{
B.O. Lukashchuk, L.G. Slivinska \\ lukaw4yk@gmail.com

\begin{abstract}
Lviv National University of Veterinary Medicine and Biotechnologies named after S.Z. Gzhytskyi, Pekarska Str., 50, Lviv, 79010, Ukraine
\end{abstract}

The article presents results of probiotic TOYOCERIN $10^{9}$ and phytobiotic EXTRACT ${ }^{\mathrm{TM}} 6930$ influence as part of the basic diet of weaned piglets with nonspecific gastroenteritis in combination with antibiotic (10\% enrofloxacin hydrochloride solution) on intestinal microbiocenosis in modern pig farm.

Using of probiotic and phytobiotic in combination with antibiotic contributed to disappearance of the major clinical symptoms in pigs of third and fourth experimental groups in 3 days after treatment, whereas in piglets of second experimental group in 5 day .

As a result of microbiological studies of weaned piglets feces with nonspecific gastroenteritis we found a change of intestinal microflora.

The use of probiotic TOYOCERIN $10^{9}$ and phytobiotic EXTRACT 6930 in combination with antibiotics (10\% enrofloxacin hydrochloride solution) for weaned piglets for 5 days helped reduce the number of pathogenic microflora to the level of healthy piglets.

Also established a positive effect of probiotic and phytobiotic in combination with antibiotic in normal microflora of gastrointestinal tract, as indicated by normalization of number of the genus Bifidobacterium and Lactobacillus representatives.

Key words: weaned piglets, antibiotic, probiotic, phytobiotic, intestinal microbiocenosis, nonspecific gastroenteritis, Enterococcus, Staphylococcus, Escherichia coli, Bifidobacterium, Lactobacillus, Candida.

\section{Вступ}

Відомо, що в кишечнику здорових тварин непатогенні та умовно-патогенні мікроорганізми знаходяться в стані симбіотичної рівноваги не тільки між собою, але й з організмом тварини-хазяїна.

У більшості видів сільськогосподарських тварин переважають представники роду Bifidobacterium, другими або третіми за кількістю є представники родів Lactobacillus або Escherichia, четвертими - роду Enterococcus, п'ятими - спороутворюючі аеробні бактерії.

Серед багатьох функцій домінуючої мікрофлори (роди Bifidobacterium і Lactobacillus), однією з найважливіших є їх участь в кооперації з організмом хазяїна в забезпеченні колонізаційної резистентності кишечника. Під якою розуміють сукупність механізмів, що надають стабільність нормальній мікрофлорі (Subbotin, 2007; Titarenko, 2010; Ostrikova, 2011; Isaacson and Kim, 2012).

Порушення екологічного балансу в середовищі існування тварин і як результат рівноваги всередині бактеріальних асоціацій кишечника призводить до зниження колонізаційної резистентності (в першу чергу родів Bifidobacterium і Lactobacillus), внаслідок цього збільшується кількість і спектр потенційно патогенних мікроорганізмів, їх транслокація або їхніх токсинів через стінку кишечника, що призводить до розвитку шлунково-кишкових захворювань.

Розвиток цих захворювань у молодняка сільськогосподарських тварин в перші $2-3$ тижні життя пов'язаний не стільки 3 елімінацією представників родів Bifidobacterium і Lactobacillus, як 3 особливос- тями становлення кишкового нормобіоза. В перші дні життя у кишечнику тварин найбільш активно заселяються представники родів Escherichia, Enterococcus, Staphylococcus та інші аеробні бактерії за рахунок характерних переваг (швидкість розмноження, властивість виробляти ендотоксини та ін.), тоді як домінування Bifidobacterium i Lactobacillus починається лише з 20 - 25 добового віку поросят.

Тому в ранньому постнатальному періоді у тварин спостерігається «природній дисбактеріоз» або «віковий дисбактеріоз», який разом 3 недостатньо вираженою імунною реактивністю та імунодефіцитним станом створюють сприятливі умови для розвитку шлунково-кишкових захворювань (Zhu, 2000; Subbotin, 2007; Kit, 2008; Pleshakova et al., 2011; BederskaLojewska and Pieszka, 2011).

Поряд з цим, безконтрольне тривале застосування кормових антибіотиків для профілактики та лікування цих хвороб тварин веде до виникнення стійкості до них мікроорганізмів. Також вони можуть негативно впливати на формування імунітету і характер імунологічних реакцій, на нервову і кровотворну систему, проявляти нефротоксичну та гепатотоксичну дію, а також викликати алергію і власне дисбактеріози (Lee et al., 2009; Kuz"menko and Chernyuk, 2012; Ahmed et al., 2014)

Тому у ветеринарній практиці все частіше використовують безпечні та ефективні альтернативи антибіотикам, у вигляді кормових добавок 3 натуральними біологічно активними речовинами, що нормалізують травні процеси в організмі, а також ефективно коригують якісний та кількісний склад мікрофлори травного каналу тварин. 
Метою досліджень було визначити вплив на кишковий мікробіоценоз пробіотика ТОЙОЦЕРІН $10^{9}$ та фітобіотика ЕКСТРАКТ ${ }^{\mathrm{TM}} 6930$ у поєднанні з антибіотиком ( $10 \%$ розчин енрофлоксацину гідрохлориду) за лікування відлучених поросят хворих неспецифічним гастроентеритом.

\section{Матеріал і методи досліджень}

Дослідження проводилися в ПАП «Агропродсервіс» (Тернопільська область). Для дослідної роботи були відібрані п'ять груп відлучених поросят (контрольна та чотири дослідні) $(\mathrm{n}=5)$ породи Ландрас віком 30 діб за принципом аналогів.

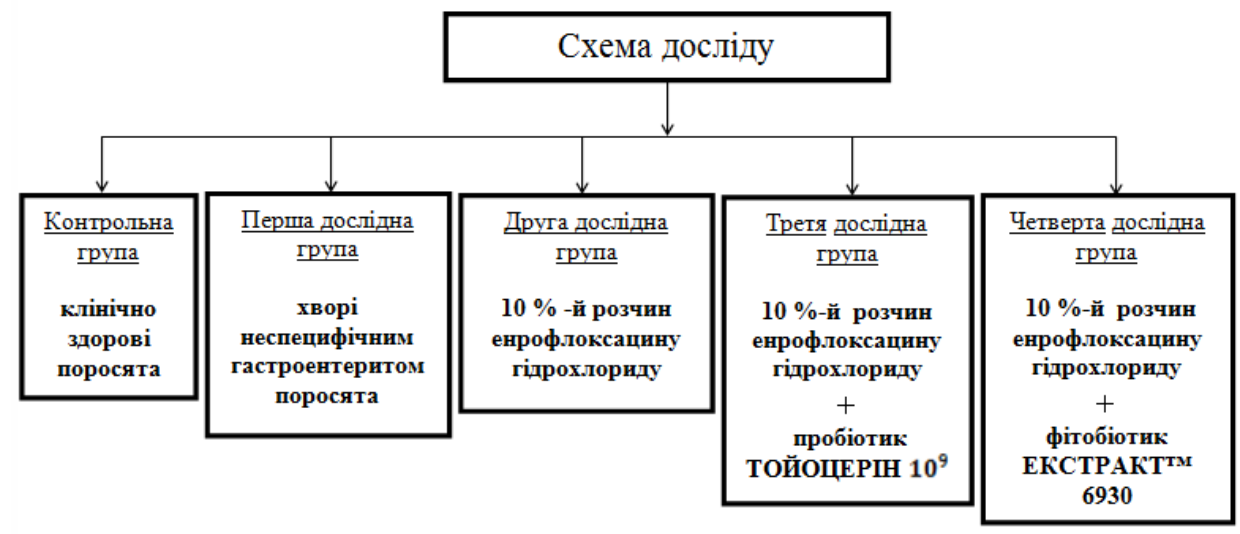

Контрольна група - клінічно здорові відлучені поросята.

Перша дослідна група - хворі на неспецифічний гастроентерит відлучені поросята.

Друга дослідна група - хворі на неспецифічний гастроентерит відлучені поросята, яких лікували за схемою господарства $(10 \%$ розчин енрофлоксацину гідрохлориду, який вводили ін'єкційно в/м у дозі 1,0 мл/20 кг маси тіла тварини один раз на добу протягом 5 діб).

Третя дослідна група - хворі на гастроентерит поросята, яких лікували застосовуючи антибіотик (10\% розчин енрофлоксацину гідрохлориду) в такій самій дозі. Додатково застосовували пробіотик ТОЙОЦЕPIH $10^{9}$ (Ломанн Анімал Нутрішн, Німеччина) у дозі 500 г/т (згідно з настанови), який додавали до комбікорму протягом 5 діб.

Четверта дослідна група - хворі на гастроентерит поросята, яких лікували застосовуючи антибіотик в такій самій дозі. Додатково застосовували фітобіотик ЕКСТРАКТ ${ }^{\mathrm{TM}} 6930$ (Панкосма С.А., Швейцарія) у дозі 150 г/т (згідно з настанови), який додавали до комбікорму протягом 5 діб.

Матеріалом для дослідження були фекалії, забір яких здійснювали стерильною скляною паличкою та поміщали в спеціальні стерильні ємності. У пробах фекалій визначали кількісний та якісний склад порожнинної мікрофлори товстої кишки.

Для цього в стерильні пробірки 3 фізіологічним розчином в об'ємі $9 \mathrm{~cm}^{3}$ від піддослідних тварин відбирали 1,0 г фекалій. 3 першої пробірки, яка вважалась за розведення $10^{-1}$, готували подальші розведення до $10^{-10}$ послідовно переносячи 1 мл суспензії в пробірки з попереднім розведенням у наступні пробірки, у яких містилось по 9,0 $\mathrm{cm}^{3}$ стерильного фізіологічного розчину.

Потім проводили висіви розведень на чашки Петрі 3 спеціальними середовищами: для роду Enterococcus - на жовчно-кров'яному МПА Бєлєнького, для роду Staphylococcus - жовтково-сольовий агар, для бакте- рій виду Escherichia coli - середовище Ендо, для роду Bifidobacterium - середовище Блаурока, для роду Lactobacillus - середовища MRS, для грибів роду Candida використовували середовище Сабуро.

Контроль клінічного статусу проводили щодобово впродовж дослідного періоду (вимірювали температуру тіла, пульс, дихання, оглядали слизові оболонки) за загальноприйнятими у ветеринарній медицині методиками (Levchenko et al., 2005).

Отримані результати експериментальних досліджень були опрацьовані стандартними методами математичної статистики з використанням програмного забезпечення Microsoft Excel. Вірогідність показників оцінювали за критерієм Стьюдента.

\section{Результати та їх обговорення}

За результатами клінічного спостереження в більшості хворих неспецифічним гастроентеритом відлучених поросят спостерігали діарею, пригнічення, спрагу та зниження апетиту за нормальної $\left(38-40^{\circ} \mathrm{C}\right)$ або субфебрильної $\left(40,5-41,0{ }^{\circ} \mathrm{C}\right)$ температури тіла. Фекалії хворих тварин були кашоподібної консистенції жовтуватого кольору, з домішками слизу.

У деяких поросят фекалії ставали рідкими, в результаті зневоднення у них спостерігалися енофтальм, сухість і складчастість шкіри. При пальпації стінки живота відмічалась болючість. Поросята швидко втрачали масу.

При важкому перебігу неспецифічного гастроентериту відмічали тахікардію (до 160 - 170 скорочень за хвилину) та тахіпное (до 45 - 60 дихальних рухів за хвилину).

У деяких поросят на 2 - 3 добу захворювання спостерігали зниження температури тіла нижче фізіологічної норми, анемічність слизових оболонок, судоми, коматозний стан та наставала загибель.

Лікування поросят, що включало застосування $10 \%$ розчину енрофлоксацину гідрохлориду сприяло поліпшенню клінічного стану хворих тварин на 5 
добу, тоді, як у поросят, яким додатково застосовували пробіотик ТОЙОЦЕРІН $10^{9}$ та фітобіотик ЕКСТРАКТ ${ }^{\text {тм }} 6930$ - на 3 добу.
У результаті проведених мікробіологічних досліджень фекалій відлучених поросят (табл.) встановлено зміни складу мікрофлори у хворих неспецифічним гастроентеритом тварин дослідних груп.

Таблиия

Кількість мікроорганізмів в 1 г фекалій поросят хворих неспецифічним гастроентеритом за різних схем лікування (M $\mathbf{m}, \mathbf{n}=\mathbf{5})$

\begin{tabular}{|c|c|c|c|c|c|}
\hline \multirow{2}{*}{$\begin{array}{c}\text { Назва } \\
\text { мікроорганізмів }\end{array}$} & \multicolumn{5}{|c|}{ Група } \\
\hline & Контрольна & Дослідна 1 & Дослідна 2 & Дослідна 3 & Дослідна 4 \\
\hline $\begin{array}{c}\text { Рід } \\
\text { Enterococcus }\end{array}$ & $4,4 \pm 2,28 \times 10^{6}$ & $6,4 \pm 2,20 \times 10^{7} *$ & $2,8 \pm 1,80 \times 10^{6}$ & $4,6 \pm 2,20 \times 10^{6}$ & $4,2 \pm 2,36 \times 10^{6}$ \\
\hline $\begin{array}{c}\text { Рід } \\
\text { Staphylococcus }\end{array}$ & $7,4 \pm 3,31 \times 10^{3}$ & $3,9 \pm 1,44 \times 10^{4} *$ & $5,2 \pm 1,46 \times 10^{3}$ & $7,2 \pm 3,28 \times 10^{3}$ & $6,0 \pm 1,52 \times 10^{3}$ \\
\hline $\begin{array}{c}\text { Вид } \\
\text { Escherichia coli }\end{array}$ & $6,1 \pm 1,09 \times 10^{6}$ & $3,1 \pm 1,27 \times 10^{8} *$ & $5,3 \pm 1,03 \times 10^{6}$ & $6,5 \pm 1,14 \times 10^{6}$ & $5,6 \pm 1,00 \times 10^{6}$ \\
\hline $\begin{array}{c}\text { Рід } \\
\text { Bifidobacterium }\end{array}$ & $6,4 \pm 2,20 \times 10^{8}$ & $4,2 \pm 2,36 \times 10^{6} *$ & $2,6 \pm 1,85 \times 10^{7} *$ & $6,4 \pm 2,20 \times 10^{8}$ & $8,2 \pm 1,80 \times 10^{8, \prime \prime 000}$ \\
\hline $\begin{array}{c}\text { Рід } \\
\text { Lactobacillus }\end{array}$ & $4,6 \pm 2,20 \times 10^{7}$ & $2,4 \pm 1,91 \times 10^{5} *$ & $6,4 \pm 2,20 \times 10^{6}$ & $8,2 \pm \underset{\text { ০০০ }}{1,80 \times 10^{8 \prime \prime \prime}}$ & $6,2 \pm 2,32 \times 10^{7}$ \\
\hline $\begin{array}{c}\text { Рід } \\
\text { Candida } \\
\end{array}$ & $2,6 \pm 1,94 \times 10^{3}$ & $3,4 \pm 1,47 \times 10^{4} *$ & $2,8 \pm 1,83 \times 10^{3}$, & $2,2 \pm 1,43 \times 10^{3}$ & $1,4 \pm 1,4 \times 10^{3}$ \\
\hline
\end{tabular}

Примітка: *-p <0,05; **-p <0,01; ***-p $<0,001$, порівняно з контрольною групою

'- $p<0,05$; "- $p<0,01$; "'-p $<0,001$, порівняно з першою дослідною групою

${ }_{-}-p<0,05 ;{ }^{\circ}-p<0,01$; ${ }^{\circ}-p<0,001$, порівняно з другою дослідною групою

У відлучених поросят першої дослідної групи за неспецифічного гастроентериту встановили вірогідне $(\mathrm{p}<0,05)$ збільшення кількості умовно-патогенної мікрофлори у фекаліях, а саме представників роду Enterococcus до 6,4 $\pm 2,20 \times 10^{7}$, роду Staphylococcus до $3,9 \pm 1,44 \times 10^{4}$, бактерій виду Escherichia coli до $3,1 \pm$ $1,27 \times 10^{8}$, грибів роду Candida до $3,4 \pm 1,47 \times 10^{4}$, порівняно 3 контрольною групою тварин.

Також у хворих тварин цієї групи встановили вірогідне $(\mathrm{p}<0,05)$ зменшення представників молочнокислої мікрофлори роду Bifidobacterium до 4,2 $\pm 2,36 \times$ $10^{6}$ та роду Lactobacillus до $2,4 \pm 1,91 \times 10^{5}$, порівняно 3 контрольною групою поросят.

У відлучених поросят другої дослідної групи встановили вірогідне $(\mathrm{p}<0,05)$ зменшення кількості умовно-патогенної мікрофлори у фекаліях (табл.) до рівня показників контрольної групи, а саме представників родів Enterococcus до 2,8 $\pm 1,80 \times 10^{6}$, Staphylococcus до $5,2 \pm 1,46 \times 10^{3}$, бактерій виду Escherichia coli до 5,3 \pm $1,03 \times 10^{6}$, роду Candida до $2,8 \pm 1,83 \times 10^{3}$, порівняно 3 показниками першої дослідної групи.

Проте встановили вірогідне $(\mathrm{p}<0,05)$ зменшення кількості представників нормальної мікрофлори роду Bifidobacterium у фекаліях поросят другої дослідної групи до $2,6 \pm 1,85 \times 10^{7}$, порівняно 3 показником контрольної групи тварин.

Також у фекаліях поросят другої дослідної групи встановили вірогідне $(\mathrm{p}<0,05)$ збільшення кількості представників нормальної мікрофлори роду Lactobacillus до $6,4 \pm 2,20 \times 10^{6}$, порівняно 3 показником першої дослідної групи.

Подібну тенденцію ( $<<0,05)$ щодо зменшення кількості умовно-патогенних мікроорганізмів у фекаліях до рівня показників контрольної групи спостерігали у відлучених поросят третьої та четвертої дослідних груп (табл.), порівняно $з$ першою дослідною групою.
Проте кількість корисної мікрофлори роду Bifidobacterium у фекаліях тварин третьої дослідної групи вірогідно збільшилась до $6,4 \pm 2,20 \times 10^{8}$ $(\mathrm{p}<0,05)$, тоді як у четвертій дослідній до $8,2 \pm$ $1,80 \times 10^{8}(\mathrm{p}<0,001)$, порівняно 3 показниками другої дослідної групи поросят.

Також вірогідно збільшилась кількість представників роду Lactobacillus до $8,2 \pm 1,80 \times 10^{8}$ ( $\left.<<0,001\right)$ та $6,2 \pm 2,32 \times 10^{7}(\mathrm{p}<0,05)$ у поросят третьої та четвертої дослідних груп, порівняно з показниками другої дослідної групи поросят.

\section{Висновки}

1. Застосування пробіотика ТОЙОЦЕРІН $10^{9}$ та фітобіотика ЕКСТРАКТтм 6930 у поєднанні 3 антибіотиком (10\% розчин енрофлоксацину гідрохлориду) сприяло скороченню терміну клінічного одужання тварин та зменшенню кількості умовно-патогенної мікрофлори до рівня показників клінічно здорових тварин.

2. Встановлено позитивний вплив ТОЙОЦЕРІН $10^{9}$ та ЕКСТРАКТтм 6930 у поєднанні з $10 \%$ розчином енрофлоксацину гідрохлориду на молочнокислу мікрофлору щлунково-кишкового тракту, на що вказує нормалізація кількості представників родів Bifidobacterium та Lactobacillus.

Перспективи подальших досліджень. Подальші дослідження будуть спрямовані на визначення впливу ТОЙОЦЕРІН $10^{9}$ та ЕКСТРАКТтм 6930 на біохімічні показники сироватки крові відлучених поросят хворих гастроентеритом незаразної етіології в умовах сучасного свинокомплексу.

\section{Бібліографічні посилання}

Ostrikova, Je.E. (2011). Vlijanie probiotikov na stanovlenie kishechnogo biocenoza u porosjat- 
sosunov. Nauchnyj zhurnal KubGAU. Krasnodar. 74(10), 799-812 (in Russian).

Subbotin, V.V. (2007). Stanovlenie normal'nogo mikrobiocenoza $\mathrm{v}$ postnatal'nom periode $\mathrm{u}$ domashnih zhivotnyh. Materialy pervogo s"ezda farmakologov Rossii. Voronezh, 570-575 (in Russian).

Titarenko, O.V. (2010). Lokalizaciya enterobakterij rodu escherichia v orhanizmi svynej. Visnyk Poltavs"koyi derzhavnoyi ahrarnoyi akademiyi. 2, 111-113 (in Ukrainian).

Isaacson, R., Kim, H.B. (2012). The intestinal microbiome of the pig. Animal Health Research Reviews. 13(1), 100-109.

Zhu, J. (2000). A review of microbiology in swine manure odor control. Agriculture, Ecosystems and Environment. 78, 93-106.

Pleshakova, V.I., Nalepova, M.Ju., Leshheva, N.A., Konev, A.V. (2011). Vidovoj sostav jenterobiocenoza porosjat $\mathrm{s}$ diarejnym sindromom $\mathrm{V}$ hozjajstvah zapadno-sibirskogo regiona. Vestnik Omskogo gosudarstvennogo agrarnogo universiteta. 1, 57-61 (in Russian).

Kit, A.A. (2008). Bakterijnyj pejzazh fekalij iz pryamoyi kyshky porosyat-sysuniv pislya zastosuvannya rozchynu poltavs"koho bishofitu. Visnyk Poltavs"koyi derzhavnoyi ahrarnoyi akademiyi. 4, 170-174 (in Russian).

Bederska-Lojewska, D., Pieszka, M. (2011). Modulating gastrointestinal microflora of pigs through nutrition using feed additives. Ann. Anim. Sci. 11(3), 333-355.

Lee, S.J., Shin, N.H., Ok, J.U. (2009). Effects of dietary synbiotics from anaerobic microflora on growth performance, noxious gas emission and fecal pathogenic bacteria population in weaning pigs. Asian-Aust. J. Anim. Sci. 22(8), 1202-1208.

Ahmed, S.T. Hoon, J., Mun, H., Yan, C. (2014). Evaluation of Lactobacillus and Bacillus-based probiotics as alternatives to antibiotics in enteric microbial challenged weaned piglets. African Journal of Microbiology Research. 8(1), 96-104.

Kuz"menko, O.A., Chernyuk, S.V. (2012). Vplyv prebiotyka ta kormovoho antybiotyka na imunolohichni pokaznyky krovi ta mikrobnyj status travnoho kanalu svynej. Zbirnyk naukovyx prac VNAU. 4(62), 10-14 (in Ukrainian).

Levchenko, V.I., Zayarnyuk, V.P., Papchenko, I.V. (2005). Hvoroby svynej [tekst]: pidruchnyk [dlya vyshhyx navch. zakl.]. Bila Cerkva (in Ukrainian).

Стаття надійшла до редакції 25.09.2016 